X-ray focusing camera, as developed by Prof. G. Hägg, of the University of Uppsala. This camera, which is probably the first of its kind to be built in Great Britain, has two major advantages over the Debye-Scherrer type of camera : the background is much less intense, so that the photographs are much sharper and weak lines are readily seen; and the errors in determining the Bragg angle $\theta$ are much smaller at low values of $\theta$, the major source of error, the absorption error, being almost entirely eliminated. This is of particular importance in indexing photographs of low-symmetry structures; indeed, there are instances in which conventional cameras fail entirely, and a Guinier-type camera is indispensable. A recent example of this is a uranium oxide phase which appeared amorphous to an ordinary camera, but gave a fully indexable picture with the Guinier. The Harwell camera was constructed in the workshops of the Atomic Energy Research Establishment, at a cost of roughly $£ 200$.

\section{Year-book of the Textile Institute for 1954-55}

THE year-book of the Textile Institute for 1954-55 (pp. 248. Manchester: Textile Institute, 1955; $15 s$.$) , besides giving many of the features of the$ previous six issues, such as lists of members and of textile and allied organizations, Institute committees, sections and branches, etc., contains details of the changes in the Institute's design competitions which take effect this year. Information about the Institute's examinations and scholarships is also included, as well as lists of the Mather Lectures, Inaugural Lectures and Emsley Lectures, and details of the Institute's publications (including text-books). In addition, the year-book gives a list of trade and technical periodicals held by the Institute, and two useful bibliographies -one of introductory textile literature, and the other a classified list of books on textile subjects, mostly books published since 1945 . There are also lists of films of textile subjects, indicating the sources from which they can be obtained, and of standard methods of testing for textiles, in which those which have been published as British Standards are distinguished.

\section{National Science Foundation, Washington, D.C. :} Fellowships for 1955-56

THE National Science Foundation, Washington, D.C., has announced the award of 715 pre-doctoral graduate fellowships and 70 post-doctoral fellowships in the natural sciences for the academic year 1955-56. Of the former, 255 fellowships have been made to first-year students, 291 to students in their intermediate years, and 169 to those in their last year. The distribution among subjects is as follows: chemistry, 167 ; physics, 151 ; engineering sciences, 107 ; mathematical sciences, 52 ; zoology, 50 ; biochemistry, 35 ; earth sciences, 30 ; psychology, 27 ; microbiology, 20 ; botany, 16; agriculture, 14; medical sciences, 11 ; geneties, 10 ; astronomy, 9 ; biophysics, 8 ; anthropology, 5 ; and general biology, 3 . Of the post-doctoral awards, 26 have been made in the life sciences, 15 in chemistry, 15 in physics and astronomy, 11 in the mathematical sciences, 2 in the engineering sciences, and 1 in the earth sciences. All the awards are tenable at any accredited non-profit educational institution of higher learning in the United States or abroad. The pre-doctoral fellowships are worth 1,400 dollars for those in their first year, rising to 1,800 dollars for those in their last year of graduate study, and post-doctoral fellowships are worth 3,400 dollars. The fellowships include additional allowances for dependants, tuition and other normal expenses.

\section{Metropolitan-Vickers Postgraduate Engineering \\ Bursaries}

Metropolitan-Vickers Electrical Co., Ltd., of Trafford Park, Manchester, has endowed four postgraduate bursaries in electrical and mechanical engineering, each worth $£ 400$ a year, in the University of Manchester ; two of these bursaries will normally be tenable in the Faculty of 'Technology of the University at the Manchester College of Technology. The Company has also endowed three similar bursaries tenable in the Mechanical and Electrical Engineering Departments of the Imperial College of Science and Technology, London. A particular purpose of these bursaries is to encourage graduates in physics and mathematics to undertake postgraduate study or research in engineering in preparation for entry into the electrical industry.

\section{British Society for Research on Ageing}

The following have been elected officers and members of the executive committee of the British Society for Research on Ageing: Chairman, Sir Charles Dodds; Vice-Chairman, Sir Francis Fraser; Secretary, Dr. G. H. Bourne (London Hospital Medical College, Turner Street, London, E.1); Treasurer, Prof. P. L. Krohn; Members of Committee, Prof. J. F. Danielli, Dr. H. B. Fell, Prof. K. J. Franklin, Prof. P. B. Medawar and Prof. R. E. Tunbridge.

\section{Colonial Service : Recent Appointments}

THE following appointments have recently been made in the Colonial Service: L. J. S. Littlejohn (chief soil conservation officer, Tanganyika), regional assistant director of agriculture, Tanganyika; J. T. Moon (assistant director of agriculture, Uganda), deputy director of agriculture, Uganda; M. F. H. Selby (chief agricultural officer, Nyasaland), assistant director of agriculture, Nyasaland; A. F. W. Sheffield (deputy director of agriculture, Eastern Region, Nigeria), director of agriculture, Eastern Region, Nigeria; A. J. Fyfe and F. H. Landon (senior assistant conservators of forests, Federation of Malaya), conservators of forests, Federation of Malaya; D. S. P. Noakes (conservator of forests, Federation of Malaya), deputy director of forestry, Federation of Malaya; H. W. Catling, archæological survey officer, Cyprus ; S. D. Gangolli, government chemist, Medical Department, Uganda; A. J. Nutten, chemist, Medical Department, Hong Kong; J. R. Charter, specialist (forest botanical ecologist), Federation of Nigeria; E. G. G. Dykes, assistant conservator of forests, British Honduras; Miss A. P. M. Lynam, records officer, Geological Survey Department, Uganda; D. J. Ducker, veterinary officer, Nyasaland; W. Foulston, veterinary officer, Northern Region, Nigeria ; B. L. Nestel, veterinary officer, Jamaica; K. Ogonowski, veterinary research officer, Kenya; and F. G. Peers, veterinary biochemist, Federation of Nigeria.

\section{Conference on Production and Utilization of Electromagnetically Enriched Isotopes}

A CONFERENCF on the "Production and Utilization of Electromagnetically Enriched Isotopes" will be hold at the Atomic Energy Research Establishment, Harwell, during September 13-16. Several leading 